\title{
Akciğer ve Prostat Kanseri için İlaç Yeniden Konumlandırmanın Uygulanması
}

\author{
Ali Cüvitoğlu ${ }^{1}$, Zerrin Işık ${ }^{2}$ \\ ${ }^{1}$ Dokuz Üniversitesi, Mühendislik Fakültesi, Bilgisayar Mühendisliği Bölümü, İzmir, Türkiye (ORCID: 0000-0002-3280-1908) \\ ${ }^{2}$ Dokuz Üniversitesi, Mühendislik Fakültesi, Bilgisayar Mühendisliği Bölümü, İzmir, Türkiye (ORCID: 0000-0003-1779-1681)
}

(International Symposium on Multidisciplinary Studies and Innovative Technologies (ISMSIT) 2020 - 22-24 October 2020)

(DOI: $10.31590 /$ ejosat.823405)

\begin{abstract}
ATIF/REFERENCE: Cüvitoğlu, A. \& Işık, Z. (2020). Akciğer ve Prostat Kanseri için İlaç Yeniden Konumlandırmanın Uygulanması. Avrupa Bilim ve Teknoloji Dergisi, (Özel Say1), 297-304.

$\ddot{O} z$

Yeni baştan ilaç geliştirme, karmaşık ve oldukça pahalı bir süreçtir. Bu nedenle, son yıllarda yeni hesaplamalı yaklaşımlar geliştirilmiştir. Hesaplamalı yaklaşımlardan biri, onaylanmış ilaçlara yeni tedavi alanını keşfeden ilaç yeniden konumlandırmadır. Çünkü ilaç yeniden konumlandırma, geleneksel ilaç geliştirme süreçlerine kıyasla daha düşük maliyet, daha kısa süre ve risksiz yatırım sağlamaktadır. Son zamanlarda, biyolojik ă tabanlı ilaç yeniden konumlandırma, proteinler arasındaki fiziksel ilişkileri veya işlevsel benzerlikleri kullandığı ve sonunda canlı sistemlerin daha iyi bir modellenebildiği için daha popüler hale geldi. Bu çalışma, hastalık genleri ve ilaçtan etkilenen genler arasındaki ăg benzerliklerini hesaplayan ve ardından en yüksek benzerlik puanlarına göre en iyi ilaç adaylarına öncelik veren ağ tabanlı yeni bir ilaç yeniden konumlandırma yöntemi sunmaktadır. Genel ağ yapısının oluşturulmasında işlevsel bir proteinprotein etkileşim ağı kullanılır. Kansere neden olan genler bu ağ yapısı üzerinde haritalandırılır. İlaçların transkriptom profilleri LINCS L1000 projesinden elde edilir ve yine ağ yapısında ayrı ayrı haritalanır. Bir hastalık ağı ile ilaçtan etkilenen bir ağın benzerliği, AdamicAdar ve Tercihli Bağlanma ağ merkezilik metrikleriyle hesaplanır. Önerilen ilaç yeniden konumlandırma yaklaşımı, anlamlı benzerlik puanlarına sahip ilaçları seçerek en iyi tedavi adaylarını belirler. Geliştirilen yöntem, insan küçük hücreli olmayan akciğer kanseri (A549) ve prostat kanseri hücre hatları (LNCAP ve PC3) üzerinde denenmiştir. Ağ merkeziliği metriklerinin AUC değerleri her iki kanser türünde de 0.8'i aşmıştır. Aday ilaçlar en yüksek AUC değerlerine göre sıralandığında, FDA onaylı on iki tedaviden beş tanesi prostat kanseri için ilk \%20 içinde yer almıştır, bu oldukça umut verici bir sonuçtur. Genel olarak, bu çalışma gelecekte gelişmeye müsait olan özgün bir ağ tabanlı ilaç yeniden konumlandırma yönteminin ilk deneysel sonuçlarını sunmaktadır.
\end{abstract}

Anahtar Kelimeler: İlaç Yeniden Konumlandırma, Akciğer Kanseri, Prostat Kanseri, Adamic-Adar, Tercihli Bağlanma.

\section{Application of Drug Repositioning for Lung and Prostate Cancer}

\begin{abstract}
De-novo drug development is complicated and quite expensive process. Therefore, new computational approaches have been developed over the last years. One of the computational approaches is drug repositioning that discovers new treatment area of approved drugs. Since drug repositioning provides lower costs, shorter time, and risk-free investment compared to the traditional drug development processes. Recently, biological network-based drug repositioning became more popular, since they use the physical relationships or functional similarities between proteins and eventually provide a better modelling of living systems. The current study presents a new network-based drug repositioning method that computes network similarities between disease genes and drug-affected genes, then prioritizes the best drug candidates based on highest similarity scores. A functional protein-protein interaction network is used in creation of the general network structure. The cancer-causing genes are mapped on this network structure. Transcriptome profiles of drugs are obtained from the LINCS L1000 project and they also mapped individually on the network structure. The similarity of a disease network and a drug-affected network is calculated by Adamic-Adar and Preferential Attachment network centrality metrics. The proposed drug repositioning approach identifies the best treatment candidates by choosing the drugs with significant similarity scores. The developed method was experimented on human non-small cell lung cancer (A549) and prostate cancer cell lines (LNCAP and PC3). The AUC values of network centrality metrics exceeded 0.8 in both cancer types. When candidate drugs are ranked based on the highest AUC values, five out of twelve FDA-approved treatments were ranked in the top $20 \%$ for prostate cancer, which is quite promising result. Overall, this study provides initial experimental results of a novel network-based drug repositioning method that is open for future developments.
\end{abstract}

Keywords: Drug Repositioning, Lung Cancer, Prostate Cancer, Adamic-Adar, Preferential Attachment. 


\section{Giriş}

İlaç yeniden konumlandırma (İYK) (ilacın yeniden kullanılması veya ilacın yeniden şekillendirilmesi olarak da bilinir), farklı bir hastalığı tedavi etmek amacıyla bilinen bir bileşiğin yeni bir kullanımını keşfetme sürecidir. Günümüzde İYK, yeni ilaçlar geliştirmekten daha popülerdir. Çünkü geleneksel yollarla yeni bir ilaç geliştirmek maliyetli bir süreçtir ve oldukça uzun bir zaman gerektirir. Aksine, IYYK daha kısa sürede daha yüksek başarı oranı verebilmektedir. Geleneksel ilaç geliştirme, keşif, preklinik, güvenlik incelemesi, klinik araştırma, FDA (The United States Food and Drug Administration) incelemesi ve pazar sonrası güvenlik izlemesi olmak üzere 5 aşamadan oluşurken, IYYK'nın 4 adımı, bileşik tanımlama, bileşik satın alma, geliştirme ve FDA pazar sonrası güvenlik izlemesidir (Xue ve diğerleri, 2018). Bir ilacı geleneksel yolla geliştirmek 10-15 yıl sürer ve ortalama \%2,01 başarı oranına sahiptir. Yeniden konumlandırılmış bir ilaç geliştirmek, buna kıyasla ortalama 8 yıla mal olmaktadır. İlaç yeniden konumlandırma, bazı nedenlerden dolayı yeni ilaç keşfinden daha etkili bir yaklaşımdır. Birincisi, ilaçların formülleri ve üretim yöntemleri zaten oluşturulmuştur. İkinci olarak, ilaçların dağılımı, metabolizması, atılımı ve toksisitesi de bilinmektedir. Diğer bir neden de ilaçların önceki klinik deneyleri güvenli bir şekilde geçmiş olması ve yan etkiler nedeniyle gelecekteki klinik deneylerde başarısız olma ihtimalinin düşük olmasıdır. Son olarak, ilaçların elde edilmesi pahalıdır ve zaman alıcı olan Faz IV güvenlilik verileri bilinmektedir.

IYK için deneysel ve hesaplamalı yaklaşımlar bulunmaktadır. Klinik düzeyde başarıya ulaşmış birkaç IYYK örneğinden bahsedecek olursak, Duloxetine, sinaptik yarıkta serotonin ve noradrenalin geri alımını engellediği için 1980'lerin sonunda depresyon tedavisinde kullanılmaya başlandı. Etki mekanizmalarını incelerken duloxetinin üretral kasılmayı arttırdığı gösterilmiştir (Thor KB ve Katofiasc, 1995). Klinik öncesi çalışmalar stres tipi idrar kaçırma (SÜI) tedavisinde kullanılabileceğini göstermiştir. Bu nedenle şu anda hem kadınlarda SÜİ tedavisi hem de depresyon tedavisi için kullanılmaktadır. Başlangıçta erkek denemeleri sırasında koroner arterleri rahatlatmak için geliştirilen Sildenafil, yan etkisinin (ereksiyon) bir sonucu olarak kullanılmış ve Pfizer şirketi tarafindan FDA onayını almıştır (Renaud RC ve Xuereb H, 2002). 1957 yılından bu yana hamile kadınların sabah bulantılarının tedavisinde kullanılan talidomid, ilerleyen yıllarda 15.000 'den fazla engelli bebeğin doğumuna neden olduğunun ortaya çıkmasıyla kesildi. 1964 yılında Jacob Sheskin, şans eseri Thalidomide'i çok ağrı çeken ve uyuyamayan bir eritema nodozum laprosum (ENL) hastasında kullandı ve hastanın yaralarında ve iltihaplarında önemli bir iyileşme gözlemledi. Talidomid, ENL tedavisinde iyi sonuçlar aldıktan sonra artık ENL tedavisinde birincil ilaç olarak kullanılmaktadır (Brynner R \& Stephens T, 2001). Talidomid, melanom gibi bazı kanserlerin tedavisinde de kullanılmıştır (Ratner ML 2001).

Deneysel yöntemler her zaman kesin sonuç veren yöntemlerdir. Bir ilaç için deney yapıldıktan sonra yeniden konumlandırılıp konumladırılamayacağı sonucu kesindir, fakat milyonlarca ilacın birçok farklı hastalık üzerinde deneysel olarak etkilerini gözlemlemek, maddi ve zaman açısından neredeyse imkânsızdır. Bu aşamada hesaplamalı yöntemler IYYK potansiyeli en yükssek ilaç-hastalık ikililerini bize sunablir. Hesaplamalı yöntemlerin son zamanlarda artışıyla birlikte, veri madenciliği tabanlı, makine öğrenmesi tabanlı, ağ tabanlı vb. şeklinde bu yöntemler kullanılan metoda göre sınıflandırılabilir. Bunlara birer örnek olarak, Li vd. hastalığa özgü ilaç-protein bağlantı haritaları oluşturmayı amaçlamıştır (Li ve diğerleri, 2009). İlk adım, ağ madenciliği kullanarak moleküler etkileşim ağlarından hastalık-protein ilişkilerini bulmaktı ve diğer bir adım da metin madenciliği kullanarak PubMed özetlerinde alzheimer hastalığını elde etmekti. Son olarak bu iki adımdan ilaç-hastalık ve hastalık-protein ilişkilerini aldıktan sonra ilaç-protein ilişkisine ulaşmışlardır. PREDICT (Gottlieb ve diğerleri, 2011), ilaç-hastalık arasındaki yeni ilişkileri bulmak için makine öğrenimini (MÖ) kullanan bir modeldir. İlk olarak OMIM (Hamosh ve diğerleri, 2002), DrugBank (Wishart ve diğerleri, 2008), DailyMed ve Drugs.com'dan veri toplarlar. İlaç-ilaç ve hastalık-hastalık benzerliği ölçütlerinin inşasından sonra, bu benzerlik ölçülerinden, sınıflandırma özelliklerini oluşturdular; doğru ve yanlış ilaç-hastalık ilişkilerini ayıran bir sınıflandırma kuralını öğrendiler. Deneylerinde 0,92 Area Under ROC (AUC) değerine ulaştılar. Başka bir çalışmada, bir ilacın fonksiyonel bağlantı ağını ve bir hastalığın bağlantı ağlarını kullanarak etkilenen alt modülleri olumsuz şekilde değiştirebilecek ilaç profilleri bulundu (Chen ve diğerleri, 2016). 'DeepDR' çalışması ise, 10 farklı ağı (tek ilaç-hastalık, bir ilaç-yan etki, bir ilaç-hedef ve yedi ilaç-ilaç ağı) entegre eden ağ tabanlı bir derin öğrenme yaklaşımıdır (Zeng ve diğerleri, 2019).

Bu çalışmada LINCS L1000 projesinden indirilen akciğer kanseri ve prostat kanseri hücre hatlarına uygulanmış ilaç verilerini kullanarak her hastalığa özgü olarak IYYK yöntemi uygulandı. Özgün olarak yeni geliştirilen bu IYYK yöntemi, proteinler arasındaki biyolojik işlev bilgisini dikkate alan bir protein-protein etkileşim ağı içermektedir, böylece ilaç tedavisi sırasında hücrede gözlemlenen değişimleri sistem biyolojisi seviyesinde dikkate alarak, daha gerçekçi bir hesaplamalı model sunulmaktadır. IYYK yönteminin hedefi, hastalığa sebep olan genleri bir etkileşim ağı içindeki biyolojik etkinliğini en iyi düzeyde değiştirebilecek potansiyel ilaçların yine ağ içinde çalışacak metrikler ile belirlenmesidir. Bu amaç doğrultusunda kansere sebep olan genler ve bir ilaçtan etkilenen proteinler aynı etkileşim ağı içinde iki ayrı modül olarak temsil edildikten sonra, bu iki modülün örtüşmesi (benzerliği) ağ topolojisine dayalı birleşik bir puana göre hesaplanmaktadır. İlk sonuçları iki ayrı kanser türü için sunulan ve özgün olarak geliştirilmiş bu İYK yönteminin, hesaplamalı kanser tedavisi öneri yaklaşımları içinde umut vaat ettiğini düşünmekteyiz.

\section{Materyal ve Metot}

\subsection{Metodun Ana Hatları}

İlaç verileri LINCS L1000 projesine ait veri tabanından indirilip işlendikten sonra Fonksiyonel Bağlantı Ağı (FBA) üzerinde haritalanmak üzere gen listesi (İlaçtan Etkilenen Proteinler-İEP) olarak hazırlanmıştır (Bölüm 2.2.2). Benzer şekilde, akciğer ve prostat kanserine sebep olan genler Hastalık Genleri (HG) literatürden elde edilmiştir (Bölüm 2.2.3). Elde edilen her bir ilaç listesi (her bir İEP) ve iki kanser türü için HGayrı ayrı FBA üzerinde haritanlanmıştır (Bkz. Şekil 1). Böylece her bir ilaç için İEP Ağı (IEPA) ve her kanser 


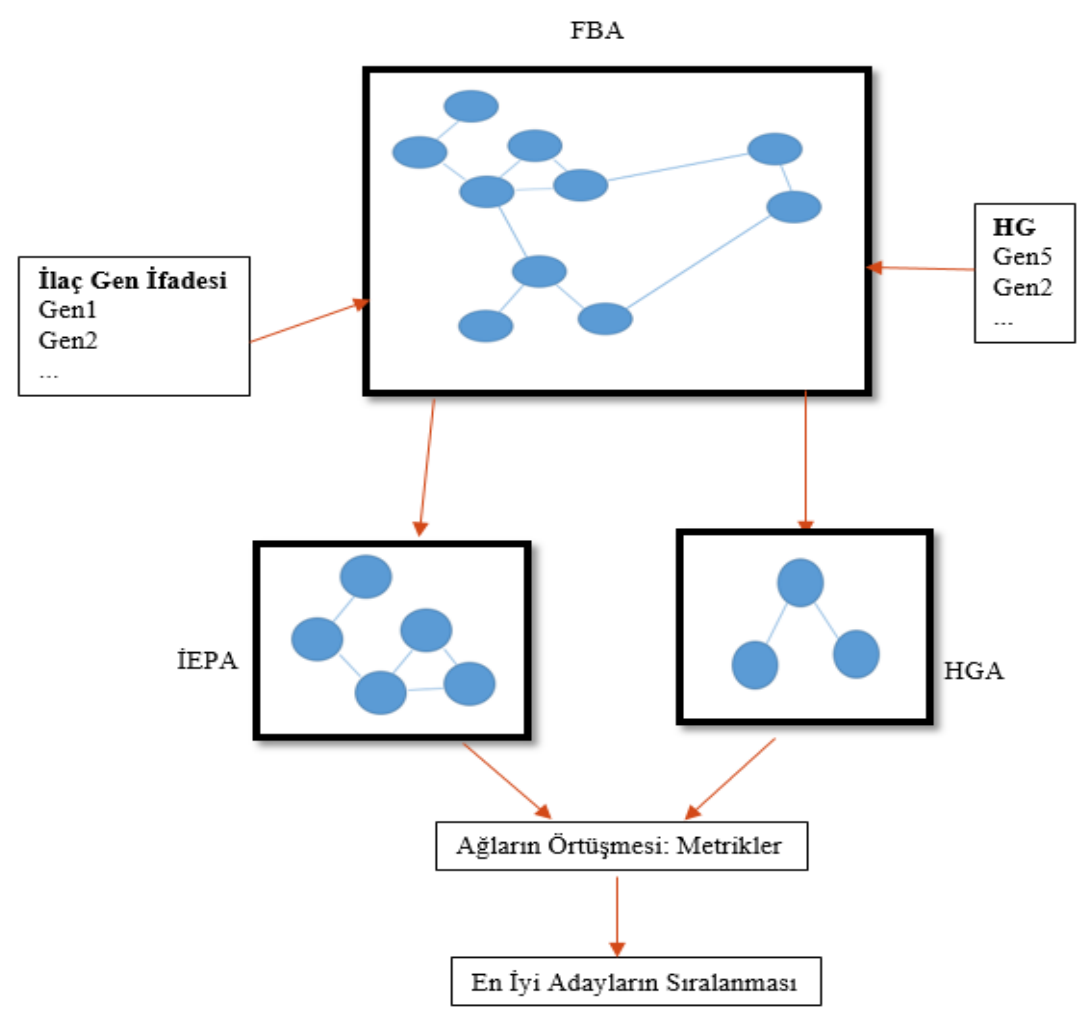

Şekil 1. Metodun Akış Diyagramı

türü için HG Ağı (HGA) elde edilmiş oldu. Akciğer kanseri için A549 hücre hattında deneyleri yapılmış her bir ilaç, akciğer HGA ile örtüşme puanını hesaplamak için iki ağ metriği uygulandı. Benzer şekilde Prostat kanseri için PC3 ve LNCAP hücre hatlarında deneyleri yapılmış ilaçların İEPA ile Prostat kanseri HGA arasında örtüşmesinin hesabı için de aynı iki metrik uygulandı. Son olarak, metrik sonuçlarına göre aynı kanser türü için ilaçlar en yüksek AUC değerinden en düşüğe doğru sıralandı.

\subsection{Veriler ve Verilerin İşlenmesi}

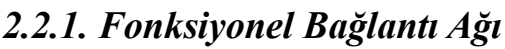

Fonksiyonel Bağlantı Ağı (FBA), proteinlerin biyolojik açıdan fonksiyon benzerliğini temsil etmek için kullanılan, ağırlıklı bir ağ yapısıdır. Bu çalışmada kullanılacak proteinlerin etkileşimi ile ilgili verileri içeren FBA literatürden elde edilmiştir (Linghu B vd., 2009). Kullanılan FBA, 20.790 proteinden (düğüm / gen), 21.952.150 etkileşimden (bağlantı) oluşmaktadır. Her bir bağlantının ağırlık değeri iki protein arasındaki biyolojik fonksiyon benzerliğini ifade etmektedir ve bu değerler 0-1 arasındadır. Fonksiyonel benzerliği çok düşük olan proteinleri ( 0 - 0.1 ağırlığındaki bağlantıya sahip olanları) FBA içinden çıkardık. Bu işlem sonrasında ağda, 15.002 protein and 334.225 bağlantı kalmıştır. Çalışmanın geri kalanında FBA diye nitelendirilen ağ, bu budama işleminden geçirilmiş ağ yapısıdır.

\subsection{2. İlaç Gen İfadesi Verisi}

Bu çalı̧̧mada kullanılacak ilaç numuneleri LINCS L1000 projesinden alınmıştır (Subramanian A vd., 2017). Bir adet akciğer kanseri hücre hattı (A549) ve iki adet prostat kanseri hücre hattı (PC3, LNCAP) üzerinde 12 ve 24 saatlik uygulamaları olan ilaç deneyleri bulunmaktadır. Her genin mRNA dizileme okuma değerlerinin, z-skoru kullanılarak normalleştirilmiş değerleri, ilaç örnekleri olarak elde edildi. İlk olarak hücre hatları için mevcut tüm ilaçlar seçildi. Ardından 24 saatlik uygulamalar ve $10 \mu \mathrm{m}$ dozundaki ilaçlar alındı. Daha sonra ihtiyaç duyulursa diğer konsantrasyonlar $(1.11 \mu \mathrm{m}$ veya $3.33 \mu \mathrm{m})$ uygulanabilecektir. Z-skoru dönüştürülmüş gen ekspresyon ölçümleri ile A549 hücre hatında 266 ilaç, PC3 ve LNCAP hücre hatlarında ise toplam 1.765 ilaç verisi elde edildi. Son olarak, tüm ilaçlar için mutlak z-skoru 1'den büyük genler alınarak, her bir ilaca özel olan ilaçtan etkilenen proteinler (IEP) elde edildi.

\subsubsection{Hastallk Genleri}

İlaç geliştirme çalışmaları çoğunlukla bir hastalığa sebep olan proteinleri etkinliğini değiştirmek amacıyla kurgulanır. Farklı kanserler için gerek gen mutasyonlar gerekse posttranslasyonel modifikasyonlar sebebiyle oluşabilmektedir. Bu sebeple İYK metodunda seçilen kansere sebep olan Hastalık Genleri (HG) yine bir ağ yapısı içinde temsil edilmesi planmıştır. Pathology Atlas projesinden, akciğer ve prostat kanserlerine özel gen ifadesi profilleri çıkarılmıştır ("The Human Protein Atlas", 2020). Akicğer kanseri HG toplam 97 gen içermektedir, prostat kanseri HG ise 248 gen içermektedir.

\subsubsection{Verilerin FBA İçinde Bütünleştirilmesi}

Her ilaç için z-skor skoru filtrelemesi ile önemli genleri çıkardıktan sonra, bu ilaçtan etkilenen gen listelerini (IEP), FBA içinde temsil etmek için özel bir bütünleştirme işlemi uygulanmıştır. Buradaki amaç belirli bir ilaca özgü olan bağımsız bir etkileşim ağı oluşturmak 


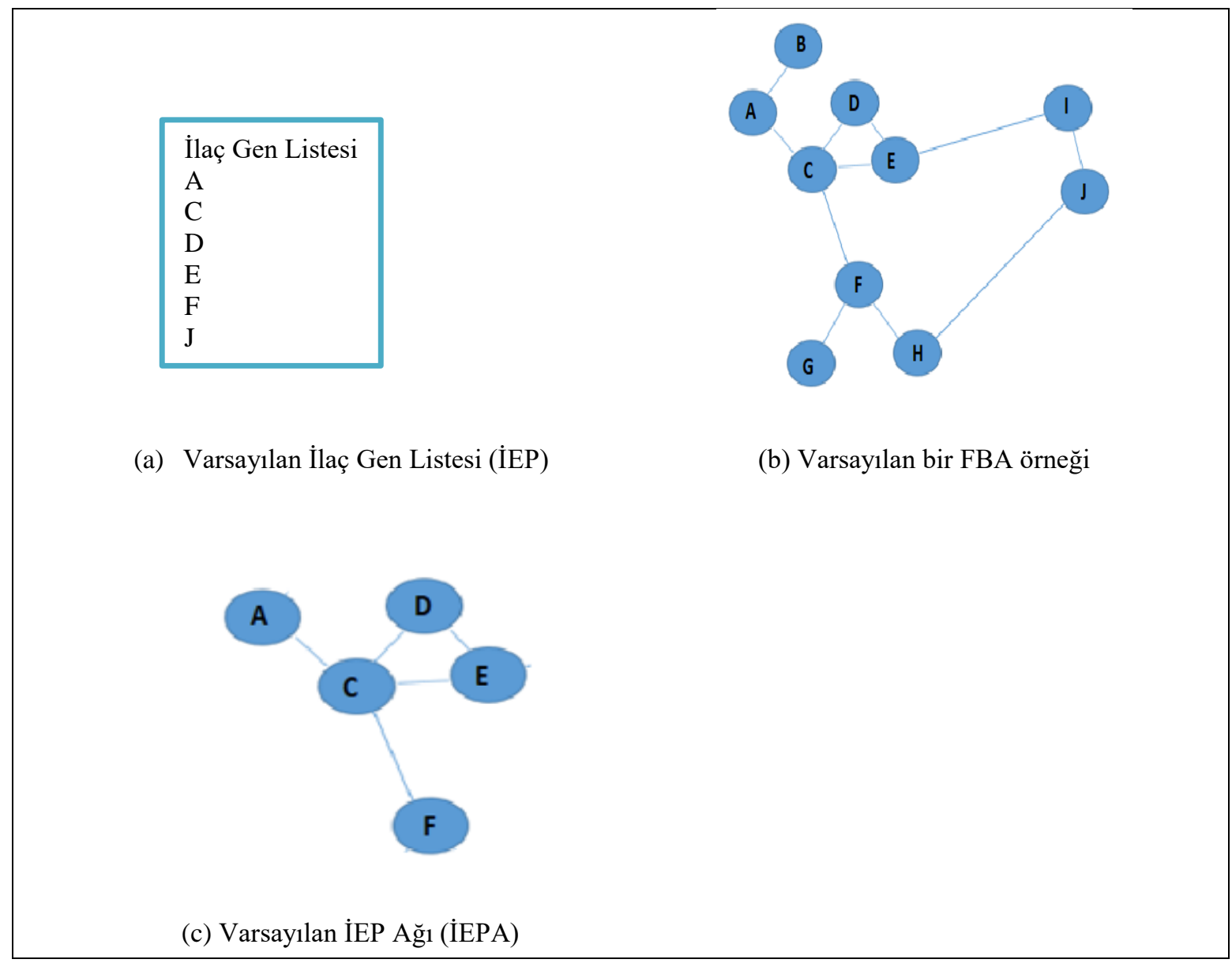

Şekil 2. Verilen bir gen listesinin FBA üzerinde haritalanması

olduğundan, FBA içinde temsil edilen gen bilgileriyle bir ilacın tedavisinden etkilenen genler arasındaki fonksiyonel etkileşimler daha etkin bir şekilde ifade edebilecektir. Bu amaçla, FBA'da yalnızca doğrudan komşu olan genleri kullanarak eşleme yapılmıştır. FBA içinde sadece İEP listesindeki genlerin kendi arasındaki direk bağlantıları kullanarak yeni bir alt ağ oluşturuldu, bu ağ yapısına doğrudan komşu haritalama ismi verildi. Böylece herhangi bir ekstra gen veya bağlantı bilgisi olmadan bir gen listesinin alt ağı oluşturuldu. Şekil 2'de verilen temsili haritalama işleminde (a) bölümünde verilen gen listesi (b) bölümündeki gibi bir FBA üzerinde haritalandığında, (c) bölümündeki gibi alt-ağ elde edilmektedir. $J$ geni için herhangi bir bağlantı kalmadı̆̆ için metrik işlemlerinde kullanılamayacaktır, bu sebeple İEP ağından tamamen çıkarılmıştır. FBA üzerinde her bir ilaç için ayrı olarak uygulanan bu haritalama işlemi sonucunda, her ilaca özel İEP Ağı (İEPA) oluşmaktadır.

\subsection{A $\breve{g}$ Metrikleri}

Bu aşamada amacımız, verilen HG modüllerini en yüksek biyolojik etkinliğe göre değiştirebilecek bir İEP modülü belirlemektir. Bu nedenle, HG ve İEPA örtüşmesi, topolojik benzerliğe dayalı birleşik bir puana göre hesaplanacaktır. Bu puanı hesaplamak için kullanılan iki ağ merkezilik ölçütü (metriği) aşağıda açıklanmıştır.

\subsubsection{Adamic-Adar Katsayısı}

Adamic-Adar Katsayısı (Adamic ve Adar, 2003) ortak bir komşu ile değerlendirilen bir gen çifti arasındaki ilişkinin ne kadar özel (veya güçlü) olduğunu ölçerek, daha az komşusu olan ortak komşulara daha fazla önem vermektedir. Adamic-Adar'ın formülü;

$$
S_{x y}=\sum_{z \in \gamma x \cap \gamma y} \frac{1}{\log _{k_{z}}}
$$

Denklem 1

' $x$ ' ve ' $y$ ' farklı genler olmak üzere, ' $S_{x y}$ ', ' $x$ ' ve ' $y$ ' geni arasındaki benzerliği temsil eder. ' $z$ ', hem ' $x$ ' hem de ' $y$ ' ile ortak olan genlerin tamamıdır. ' $k_{z}$ ', ' $z$ ' geninin ağ içindeki toplam komşu sayısıdır. Bu denklemin hesabı için R-Bioconductor içindeki igraph paketindeki 'similarity' fonksiyonu uygulanmıştır. Bu fonksiyonda, Adamic-Adar'ı temsil etmek için parametre "invlogweighted" olarak seçilmiştir.

\subsubsection{Tercihli Băglanma}

Tercihli bağlanma, genleri derecesiyle (toplam komşu sayısıyla) doğru orantılı olarak genler arasındaki yeni bir bağlantı oluşma ihtimalini hesaplar (Barabási \& Albert, 1999). Tercihli bağlanma formülü;

$$
S_{x y}=k_{x} * k_{y}
$$

Denklem 2

' $x$ ' ve ' $y$ ' farklı genler olduğunda ' $S_{x y}$ ', ' $x$ ' ve ' $y$ ' geni arasındaki benzerliği temsil eder. ' $k_{x}$ ' ve ' $k y$ ', sirasıyla ' $x$ ' ve ' $y$ ' geninin derecesini temsil eder. Bu ölçüt için herhangi bir paket kullanılmamıştır. 


\subsubsection{Metriklerin Uygulanmast}

Seçilen metrikler hesaplandıktan sonra, bir gen için özet bir benzerlik puanı oluşturabilmek için tüm değerlerin toplanması yöntemi kullanılmıştır. Denklem 3'te görüleceği gibi bir $x$ geninin benzerlik puanı, diğer tüm $y$ genleriyle olan benzerliklerinin toplamıyle ifade edilmektedir.

$$
S_{x}=\sum_{y \in N} S_{x y}
$$

Denklem 3

Burada ' $S_{x}$ ', ' $x$ ' geninin benzerlik puanıdır. ' $N$ ' ise ağdaki tüm genleri içerir. ' $S_{x y}$ ', ' $x$ ' ve ' $y$ ' geni arasındaki benzerliği temsil eder ve ' $y$ ' ağdaki diğer genleri temsil eder.

\subsection{Değerlendirme}

Farklı biyolojik hipotezleri uygulayan her ölçüt, ağdaki her gen için bir puan hesaplayacaktır. Buradki ağ yapısı, İlaçtan Etkilenen Proteinler Ağı (İEPA) veya Hastalık Genleri Ağı (HGA) olabilir. İEP'deki tüm proteinler için hesaplanan benzerlik puanı büyükten küçüğe doğru sıralanır. Bu sıralı liste her bir ilaç için ayrı ayrı incelenmiștir. HG modülünün üyesi olan bir eşik değerinin üstünde ve altında listelenen proteinleri (örneğin, en üst-p $=100$ protein) kontrol edildi. Hem en üst-p'den daha yukarıda bir sırada olan hem de HG üyesi olan bu tür proteinlerin toplam sayısı, gerçek pozitif (GP) proteinler olarak kaydedilecektir. Gerçek negatifler (GN), en üst p sırasından daha düşük bir sıraya sahip olan ve HG genlerini içermeyen proteinlerdir. Yanlış pozitif (YP) proteinler, en üst $p$ sırasından daha yukarıda listelenir ve HG genlerini içermez. Yanlış negatifler (YN), en üst p sıralamasından daha aşağıda listelenir ve HG'de içindeki genleri içerir. Her ilaç için GP, GN, YP ve YN değerleri, tek bir karışıklık matrisini tamamlayan bir eşik (p) değerine göre sıralanmış bir liste içinde belirlenecektir. Bir karışıklık matrisi içinden Gerçek Pozitif Oran ve Yanlış Pozitif Oran hesaplandığında, bir ROC eğrisindeki bir noktayı ifade eder. ROC eğrisinde 100 ayrı ölçüm elde etmek için 100 farklı eşik değeri (her ilaç için gen sayısının $\% 1, \% 2, \ldots, \% 100)$ uygulandı. Ardından, her bir ilaç için AUC puanı olarak adlandırılan ROC eğrisi altındaki alan hesaplandı. Metriklerde İEP kullanıldığında ve karışıklık matrisi oluşturmak için çekirdek (referans seti) olarak HG kullanıldığında buna $A U C_{i E P}$ puanı denildi. Aynı fikir tersine uygulandığında, İKP üzerinde metrikler çalıştırılırken, $A U C_{H G}$ puanını hesaplamak için İEP çekirdek haline geldi. Son olarak, İEP-HG eşleştirme puanı, denklem 4'teki gibi bir birleşik AUC puanını hesaplamak için entegre edilmiştir.

$$
\text { Birleşik. AUC }=\sqrt{A U C_{\mathrm{I} E P} * A U C_{H G}}
$$

Denklem 4

Her ilaç için, birleşik bir AUC puanı elde edilir ve her metrik için ilaçlar bu birleşik-AUC puanına göre en yüksekten en düşüğe doğru siralanır.

\section{Araştırma Sonuçları ve Tartışma}

\subsection{Akciğer Kanseri Sonuçları}

LINCS L1000 projesinden elde edilen A549 hücre hattında uygulanmıș toplam 266 ilaç için İEPA'lar, sırasıyla akciğer HG'siyle iki metriğe de girdi olarak verildi. AUC hesaplamalarından sonra birleşik-AUC değerleri göz önüne alınarak ilaçların en yüksek puandan en düşüğe doğru sıralamaları yapılmıştır. Akciğer kanseri için FDA onaylı ve klinik tedavide güncel olarak kullanılan ilaçlardan 10 tanesi, veri kümesi içinde yer alan 266 ilacın içinde bulunmaktadır. Elde edilen sıralamalarda toplam 266 ilacın ilk \%20'lik bölümünde (ilk 53 ilaç) giren FDA onaylı ilaç sayılarına ve yerlerine bakılmıştır. Adamic-Adar metriğinde FDA onaylı 10 ilaçtan Afatinib ilk \%20'lik bölüme girerken, Tercihli bağlanma metriğinde iki ilaç (Afatinib, Alectinib) bu bölüme girmiş̧tir. Adamic-Adar metriğinde ilk $\% 20$ 'lik bölümdeki ilaçların birleşik-AUC değerleri 0.82 ile 0.5 aralığındadır (Tablo 1). Öte yandan Tercihli Bağlanma metriğinde bu değerler 0.77 ile 0.5 aralığındadır (Tablo 2). Adamic-Adar metriği birleșik-AUC değeri bakımından Tercihli Bağlanma metriğinden daha yüksek değerler elde etmiş olsa da FDA onaylı bilinen iki ilacın ilk \%20'lik bölümde yer alması sebebiyle, bu veri kümesinde Tercihli Bağlanma metriğinin performansının daha iyi olduğu söylenebilir.

Tablo 1. IYK yönteminin akciğer kanseri için A549 hücre hattındaki Adamic-Adar metriği kullanılarak elde edilen sonuçları. Yeşil renkle işaretli ilaç akciğer kanseri tedavisi için onaylanmış, klinikte kullanılmaktadır. (Değerler virgülden sonra ikinci basamağa kadar

\begin{tabular}{|c|c|c|c|c|}
\hline \multicolumn{5}{|c|}{ Adamic-Adar } \\
\hline Sira & İlaç Adı & AUCí̇p & $\mathbf{A U} \mathbf{C}_{\mathbf{H G}}$ & Birleşik AUC \\
\hline 1 & TWS-119 & 0,91 & 0,75 & 0,82 \\
\hline 2 & ibrutinib & 0,75 & 0,79 & 0,77 \\
\hline 3 & rucaparib & 0,64 & 0,92 & 0,77 \\
\hline$\ldots$ & $\ldots$ & $\ldots$ & $\ldots$ & $\ldots$ \\
\hline 27 & afatinib & 0,53 & 0,59 & 0,56 \\
\hline$\ldots$ & $\ldots$ & $\ldots$ & $\ldots$ & $\ldots$ \\
\hline 53 & HMN-214 & 0,44 & 0,57 & 0,50 \\
\hline
\end{tabular}
yuvarlanmıştır.) 


\subsection{Prostat Kanseri Sonuçları}

Benzer bir değerlendirme süreci prostat kanseri veri kümesi için uygulandığında toplam 1765 ilaç içerisinde FDA onaylı olduğu bilinen 12 ilaç yer almaktadır. Benzer şekilde ilk \%20'lik bölüm (ilk 353 ilaç) incelendiğinde Adamic-Adar metriğinde adet FDA onaylı dört ilaç (bicalutamide, aminoglutethimide, flutamide, cabazitaxel), Tercihli Bağlanma metriğinde beş ilaç (diethylstilbestrol, aminoglutethimide, bicalutamide, flutamide, cabazitaxel) yer almıştır. Adamic-Adar metriğinde \%20’lik bölümde birleşik-AUC değerleri 0.84 ile 0.53 arasında iken (Tablo 3), Tercihli Bağlanma metriğinde ise bu değerler 0.85 ile 0.54 arasındadır (Tablo 4). Akciğer kanseri sonuçlarıyla benzer bir çıkarım yaparak, prostat kanseri veri kümesi üzerinde de Tercihli bağlanma metriğinin klinik tedavi için onay almış ilaçların seçiminde daha başarılı olduğu söylenebilir.

Tablo 2. IYK yönteminin akciğer kanseri için A549 hücre hattındaki Tercihli Bağlanma metriği kullanılarak elde edilen sonuçları. Yeşil renkle işaretli ilaçlar akciğer kanseri tedavisi için onaylanmıs, klinikte kullanılmaktadır. (Değerler virgülden sonra ikinci basamağa kadar yuvarlanmıştır.)

\begin{tabular}{|c|c|c|c|c|}
\hline \multicolumn{5}{|c|}{ Tercihli Bağlanma } \\
\hline Sıra & İlaç Adı & AUCiEP & AUC $_{\text {HG }}$ & Birleşik AUC \\
\hline 1 & rucaparib & 0,64 & 0,92 & 0,77 \\
\hline 2 & HG-6-64-01 & 0,84 & 0,70 & 0,77 \\
\hline 3 & ibrutinib & 0.75 & 0.79 & 0.77 \\
\hline$\ldots$ & $\ldots$ & $\ldots$ & $\ldots$ & $\ldots$ \\
\hline 29 & afatinib & 0,53 & 0,59 & 0,56 \\
\hline$\ldots$ & $\ldots$ & $\ldots$ & $\ldots$ & $\ldots$ \\
\hline 47 & alectinib & 0,46 & 0,57 & 0,51 \\
\hline$\ldots$ & $\ldots$ & $\ldots$ & $\ldots$ & $\ldots$ \\
\hline 53 & NVP-BHG712 & 0,33 & 0,75 & 0,5 \\
\hline
\end{tabular}

Tablo 3. IYK yönteminin prostat kanseri için PC3 ve LNCAP hücre hattındaki Adamic-Adar metriği kullanılarak elde edilen sonuçları. Yeşil renkle işaretli ilaçlar prostat kanseri tedavisi için onaylanmış, klinikte kullanılmaktadır. (Değerler virgülden sonra ikinci basamă̆a kadar yuvarlanmıştır.)

\begin{tabular}{|c|c|c|c|c|}
\hline \multicolumn{5}{|c|}{ Adamic-Adar } \\
\hline Sıra & İlaç Adı & AUCiEP & AUC $_{\text {HG }}$ & Birleşik AUC \\
\hline 1 & amlodipine & 0,75 & 0,96 & 0,85 \\
\hline 2 & PF-04620110 & 0,86 & 0,79 & 0,83 \\
\hline 3 & cabergoline & 0,79 & 0,81 & 0,80 \\
\hline$\ldots$ & $\ldots$ & $\ldots$ & $\ldots$ & $\ldots$ \\
\hline 95 & bicalutamide & 0,52 & 0,74 & 0,62 \\
\hline$\ldots$ & $\ldots$ & $\ldots$ & $\ldots$ & $\ldots$ \\
\hline 130 & aminoglutethimide & 0,58 & 0,63 & 0,61 \\
\hline$\ldots$ & $\ldots$ & $\ldots$ & $\ldots$ & $\ldots$ \\
\hline 216 & flutamide & 0,53 & 0,62 & 0,57 \\
\hline$\ldots$ & $\ldots$ & $\ldots$ & $\ldots$ & $\ldots$ \\
\hline 242 & cabazitaxel & 0,48 & 0,67 & 0,56 \\
\hline$\ldots$ & $\ldots$ & 0,40 & 0,72 & $\ldots$ \\
\hline 353 & clonidine & & & 0,54 \\
\hline
\end{tabular}


Tablo 4. IYK yönteminin prostat kanseri için PC3 ve LNCAP hücre hattındaki Tercihli Bağlanma metriği kullanılarak elde edilen sonuçları. Yeşil renkle işaretli ilaçlar prostat kanseri tedavisi için onaylanmış, klinikte kullanılmaktadır. (Değerler virgülden sonra ikinci basamă̆a kadar yuvarlanmıştır.)

\begin{tabular}{|c|c|c|c|c|}
\hline \multicolumn{5}{|c|}{ Preferential Attachment } \\
\hline Sira & İlaç Adı & AUCiEP $_{\text {in }}$ & $\mathbf{A U C}_{\mathbf{H G}}$ & Birleşik AUC \\
\hline 1 & amlodipine & 0,75 & 0,96 & 0,85 \\
\hline 2 & PF-04620110 & 0,83 & 0,78 & 0,80 \\
\hline 3 & cabergoline & 0,78 & 0,80 & 0,79 \\
\hline$\ldots$ & $\ldots$ & $\ldots$ & $\ldots$ & $\ldots$ \\
\hline 102 & diethylstilbestrol & 0,43 & 0,88 & 0,62 \\
\hline$\ldots$ & $\ldots$ & $\ldots$ & $\ldots$ & $\ldots$ \\
\hline 127 & aminoglutethimide & 0,59 & 0,63 & 0,61 \\
\hline$\cdots$ & $\cdots$ & $\cdots$ & $\cdots$ & $\cdots$ \\
\hline 135 & bicalutamide & 0,52 & 0,70 & 0,60 \\
\hline$\ldots$ & $\ldots$ & $\ldots$ & $\ldots$ & $\ldots$ \\
\hline 224 & flutamide & 0,53 & 0,62 & 0,57 \\
\hline$\cdots$ & $\cdots$ & $\cdots$ & $\cdots$ & $\cdots$ \\
\hline 262 & cabazitaxel & 0,48 & 0,66 & 0,56 \\
\hline$\cdots$ & $\ldots$ & $\ldots$ & $\ldots$ & $\ldots$ \\
\hline 353 & aripiprazole & 0,48 & 0,61 & 0,54 \\
\hline
\end{tabular}

\section{Sonuç}

Hesaplamalı yaklaşım olarak sunulan ilaç yeniden konumladırma yöntemlerini geliştirmek oldukça karmaşık bir süreçtir. Hem ilaçların kimyasal ve metabolik etkilerinin göz önüne alınması hem de hastalıkların gen ve protein düzeyindeki ölçümlerinin hesaba katılması gerekmektedir. IYKK yöntemi sonucunda performansı yüksek olarak hesaplanan bir ilacın gerçekten başarılı bir yeniden konumlandırma olup olmadığını sadece hesaplamalı yöntemlerle kesin olarak ispatlamak oldukça zordur. Bu sebeple bu aşamadan sonra, olası en iyi değerleri veren ilaçlar ıslak laboratuvar ortamında hücre ve hayvan deneyleri sonuçlarına göre değerlendirilmelidir.

Yaptığımız bu çalışmada geliştirdiğimiz IYKK yöntemi bazı basamaklarında değiştirilebilir ve geliştirebilir durumdadır. Bunun en güçlü göstergelerinden biri, farklı kanser türleri için farklı sonuçların elde edilmesi ve veri kümesindeki ilaç sayısı arttıkça yöntemin performansının artmasıdır. Yeni ağ metrikleri hesaplanarak mevcut puanlamalar daha iyi hale getirilebilir. Uyguladığımız iki metrik genel olarak bazı ilaçlar için yakın sıralamalar vermiş olsa da klinikte kullanılan kanser tedavisi ilaçları ele alındığında şu an için Tercihli Bağlanma metriği daha iyi sonuçlar vermiştir. Bu gözlem, geliştirilecek yeni ağ metriklerinin IYYK yönteminin performans artışında etkili olabileceğini göstermektedir. Sunulan IYK yöntemiyle potansiyel yeni tedavi adaylarını belirlemek mümkündür. Geliştirilen yöntemin çalışması sonucunda en yüksek puanları alarak ilk üç sıraya yerleşen ilaçların, akciğer ve prostat kanseri tedavileri için yeni alternatif ilaçlar olabileceği düşünülmektedir. Bu ilaçların ilgili kanser türlerindeki etkinlikleri çalışmanın sonraki safhasında ıslak laboratuvar ortamında hücre deneyleriyle doğrulanacaktır. Özetle bu çalışmada ilk sonuçları sunulan ve özgün olarak geliştirilmiş IYYK yöntemi, hesaplamalı tedavi öneri yaklaşımları içinde umut vaat etmekte ve geliştirilmeye açık bir yöntemdir.

\section{Teşekkür}

Bu çalışma Tübitak 318S276 nolu proje tarafından desteklenmektedir.

\section{Kaynakça}

Adamic, L., \& Adar, E. (2003). Friends and neighbors on the Web. Social Networks, 25(3), 211-230.

Barabási, A., \& Albert, R. (1999). Emergence of Scaling in Random Networks. Science, 286(5439), 509-512.

Brynner, R. \& Stephens, T. (2001) Dark Remedy: The Impact of Thalidomide and Its Revival as a Vital Medicine (Perseus Publishing, Cambridge).

Chen, H., Sherr, D., Hu, Z. and DeLisi, C. (2016). A network based approach to drug repositioning identifies plausible candidates for breast cancer and prostate cancer. BMC Medical Genomics, 9(1).

Gottlieb, A., Stein, G., Ruppin, E., \& Sharan, R. (2011). PREDICT: a method for inferring novel drug indications with application to personalized medicine. Molecular Systems Biology, 7(1), 496. 
Hamosh A, Scott AF, Amberger J, Bocchini C, Valle D, McKusick VA (2002) Online Mendelian Inheritance in Man (OMIM), a knowledgebase of human genes and genetic disorders. Nucleic Acids Res 30: 52-55.

Li, J., Zhu, X., \& Chen, J. (2009). Building Disease-Specific Drug-Protein Connectivity Maps from Molecular Interaction Networks and PubMed Abstracts. Plos Computational Biology, 5(7), e1000450.

Linghu, B., Snitkin, E., Hu, Z., Xia, Y. and DeLisi, C. (2009). Genome-wide prioritization of disease genes and identification of diseasedisease associations from an integrated human functional linkage network. Genome Biology, 10(9), p.R91.

Ratner, M. L. (2001) Celgene backs into biotech. In Vivo 15, 15.

Renaud, R. and Xuereb, H. (2002). Erectile-dysfunction therapies. Nature Reviews Drug Discovery, 1(9), pp.663-664.

Subramanian, A., Narayan, R., Corsello, S., Peck, D., Natoli, T., \& Lu, X. et al. (2017). A Next Generation Connectivity Map: L1000 Platform and the First 1,000,000 Profiles. Cell, 171(6), 1437-1452.e17.

The Human Protein Atlas. (2020). Retrieved 17 July 2020, from https://www.proteinatlas.org/.

Thor, K. B. \& Katofiasc, M. A. (1995) Effects of duloxetine, a combined serotonin and norepinephrine reuptake inhibitor, on central neural control of lower urinary tract function in the chloralose-anesthetized female cat. J. Pharmacol. Exp. Thera. 274, 1014-1024.

Wishart DS, Knox C, Guo AC, Cheng D, Shrivastava S, Tzur D, Gautam B, Hassanali M (2008) DrugBank: a knowledgebase for drugs, drug actions and drug targets. Nucleic Acids Res 36: D901-D906.

Xue, H., Li, J., Xie, H., \& Wang, Y. (2018). Review of Drug Repositioning Approaches and Resources. International Journal of Biological Sciences, 14(10), 1232-1244.

Zeng, X., Zhu, S., Liu, X., Zhou, Y., Nussinov, R. and Cheng, F. (2019). deepDR: a network-based deep learning approach to in silico drug repositioning. Bioinformatics. 